Abstracta Iranica Abstracta Iranica

Revue bibliographique pour le domaine irano-aryen

Volume 25 | 2004

Comptes rendus des publications de 2002

\title{
Arab-Sasanian Copper Coinage. Veröffentlichungen der numismatischen Kommission, Band 34, Wien, Österreichische Akademie der Wissenschaften, 2000, 208 p., 15 pl.
}

\section{Rédaction}

\section{OpenEdition}

Journals

Édition électronique

URL : http://journals.openedition.org/abstractairanica/4358

ISSN : 1961-960X

Éditeur :

CNRS (UMR 7528 Mondes iraniens et indiens), Éditions de l'IFRI

Édition imprimée

Date de publication : 15 mai 2004

ISSN : 0240-8910

Référence électronique

Rédaction, «Arab-Sasanian Copper Coinage. Veröffentlichungen der numismatischen Kommission, Band 34, Wien, Österreichische Akademie der Wissenschaften, 2000, 208 p., 15 pl. », Abstracta Iranica [En ligne], Volume 25 | 2004, document 98, mis en ligne le 15 mars 2006, consulté le 25 septembre 2020. URL : http://journals.openedition.org/abstractairanica/4358

Ce document a été généré automatiquement le 25 septembre 2020.

Tous droits réservés 


\section{Arab-Sasanian Copper Coinage. Veröffentlichungen der numismatischen Kommission, Band 34, Wien, Österreichische Akademie der Wissenschaften, 2000, 208 p., 15 pl.}

\section{Rédaction}

1 Ce livre réunit les monnaies de cuivre frappées au cours des premières cent cinquante années de la domination arabe dans les régions anciennement sassanides. Le corpus comprend quelque 330 monnaies qui permettent de distinguer plus de cent différents types. Ceux-ci sont illustrés et décrits dans un catalogue organisé d'après les ateliers monétaires comme cela a été préconisé par les spécialistes de la numismatique arabosassanide. Toutefois un tel arrangement est peu commode et convaincant d'autant plus que de nombreuses monnaies ne portent pas un nom d'atelier monétaire. Afin de mettre en évidence les cohérences iconographiques entre cette centaine de types, un "conspectus" graphique a été aj outé au catalogue. En effet, peu de ces types monétaires suivent fidèlement le modèle du monnayage d'argent arabo-sassanide. En revanche on peut y déceler de nombreuses autres influences iconographiques - sassanide, byzantin ou umayyade - dont le prototype n'est pas nécessairement monétaire. Aussi le contenu des inscriptions en pehlevi et en arabe présente une grande variété avec des formules souvent non attestées ailleurs. Plusieurs chapitres du livre sont consacrés à l'étude de ces spécificités. 
INDEX

Thèmes : 3.2.3. Séleucides, Parthes et Sassanides

\section{AUTEURS}

RÉDACTION

Directeur de la revue et secrétariats (Paris et Téhéran) 